\title{
Yield, Keeping Quality, Antioxidant Content and Some Nutritional Aspects of Selected Accessions of Amaranthus Tricolor
}

\author{
P. Malathy, D. D. Suraweera, W. A. M. Daundasekara, W. D. G. P. Nilanthi, and K. B. Wahundeniya
}

\begin{abstract}
The Department of Agriculture (DOA), Sri Lanka has given priorities to identify new leafy vegetable varieties with high yielding capacity and superior in nutritional quality. As a part of this activity, yield potential, nutritional values and antioxidant properties of some promising accessions of Amaranthus tricolor were studied with the aim of selecting better varieties. Experiments were carried out using three new accessions; 'DOA Red', 'Pure green' and 'Diyapalagoda' along with the recommended variety, ' $\mathrm{DOA}$ green'. Yield potential was determined through growth and yield parameters. Comparison of leaf protein levels was done by Kjeldahl method. Carotenoid, anthocyanin, chlorophyll levels and the antioxidant activity of the leaves of four accessions was determined by UV-spectrophotometry. Postharvest keeping quality among accessions was compared under three storage condition: cut stem ends dipped in water and stored under ambient conditions, packaged in Low Density Polyethylene (LDPE) film and stored under ambient conditions, packaged in LDPE and stored under $10^{\circ} \mathrm{C}$ and $90 \% \mathrm{RH}$. Shelf life was determined using visual quality. 'DOA Red' contained higher amount of chlorophyll, anthocyanin and the greatest antioxidant activity. 'DOA green' and 'DOA Red' contained relatively higher percentage of crude protein. 'DOA Red' exhibited significantly longer shelf life under all three storage conditions. Polyethylene film packaging, combined with low temperature storage extended the keeping quality by $4.8-8$ fold in A. tricolor. 'Pure green' exhibited higher growth and yield performance and wider adaptability, hence it could be recommended for commercial cultivation.
\end{abstract}

Index Terms-Amaranthus, antioxidant, leafy vegetables, shelf life.

\section{INTRODUCTION}

Leafy vegetables are source of macro- and micronutrients that play a major role in maintaining healthy life. Daily dietary intake of leafy vegetables would help reducing the malnutrition problem since they provide essential minerals, vitamins and amino acids that are absent in the rice-based diet They are less expensive and easily found in any part of this country compared to other vegetables. Amaranthus tricolor (Amaranth) is one of the popular leafy vegetables in Sri Lanka due to its easiness in culture, fast growth rate,

Manuscript received August 8, 2012; revised September 17, 2012.

P. Malathy, W. D. G. P. Nilanthi, and K. B. Wahundeniya are with the Horticultural Crops Research and Development Institute, Department of Agriculture, Gannoruwa, Peradeniya, Sri Lanka. 20400 (e-mail: mpmalathy@yahoo.com, bandarawahundeniya@yahoo.com).

D. D. Suraweera and W. A. M. Daundasekara are with the Department of Botany, Faculty of Science, University of Peradeniya, Sri Lanka. 20400 (e-mail: dilsuraweera@gmail.com, malkanthid@pdn.ac.lk). adaptability to varying agro climates and high yield potential. It fits well into crop rotation due to very short crop duration and large yield of edible matter per unit area [1]. A. tricolor leaves are reported to contain high amount of crude protein and nutritionally critical amino acids viz. lysine and methionine [2] in addition to dietary fiber, vitamins and dietary minerals [3]. It is reported to contain high amount of antioxidant compounds [4] including vitamin C, carotenoids and phenolic compounds such as flavonoids [5]. Short shelf life is one of the major problems associated with this crop [6]. There is very little scientific research done on its postharvest aspects.

In Sri Lanka, different selections of A. tricolor are cultivated by farmers, but very little information is available on their growth and yield performance, nutritional value and other quality characteristics. This may lead to cultivation of poor quality varieties with low yield [7]. Hence, several accessions of A. tricolor have been collected from farmer fields, purified and subjected to yield and quality evaluation at the Horticultural Crops Research and Development Institute (HORDI). To identify varieties with better adaptation to any particular location, it is important to compare the yield potential during different growing seasons Together with morphological and ecological characterization and yield evaluation, antioxidant activity also can be used as a relatively novel index for the selection of superior varieties [8]. Therefore, yield potential, some nutritional aspects, antioxidant properties and postharvest keeping quality of some promising accessions of $A$. tricolor were studied with the aim of selecting better varieties for commercial cultivation.

\section{MATERIALS AND METHODS}

Experiments were conducted at the HORDI in four growing seasons during 2010-2011using four selected accessions, 'DOA red', 'Pure green', 'Diyapalagoda' and 'DOA green' (check variety) of A. tricolor to study their growth and yield performance, nutritional value with special reference to protein level, plant pigment content and antioxidant activity in leaves and postharvest keeping quality. Field experiments were laid out in a Randomized Complete Block Design with four replicates. Cultivation practices recommended by DOA, Sri Lanka were adopted. Complete Randomized Design with six replicates was used for biochemical and postharvest studies. 


\section{A. Comparison of the Growth and Yield Parameters of Four a. Tricolor Accessions}

Growth parameters viz. plant height $(\mathrm{cm})$, number of leaves, stem circumference $(\mathrm{cm})$, length of the $3^{\text {rd }}$ internode $(\mathrm{cm})$, width $(\mathrm{cm})$ and length of the $6^{\text {th }}$ leaf $(\mathrm{cm})$ were measured in addition to fresh weight per plant $(\mathrm{g})$ and leaf, stem and root weight in wet and dry basis and total yield (mt/ha).

\section{B. Determination of the Amount of Crude Protein}

The crude protein content in leaves was determined using Kjeldahl method [9].

\section{Determination of Carotenoid, Chlorophyll and Anthocyanin Levels}

Absorbance of leaf extract at $470 \mathrm{~nm}, 537 \mathrm{~nm}, 647 \mathrm{~nm}$ and $663 \mathrm{~nm}$ was measured using spectrophotometer (UV 1800 Japan) [10]. Concentration of carotenoids, chlorophylls and anthocyanin were calculated by following equations [11], and the values were converted to $\mu \mathrm{g} / \mathrm{cm}^{2}$.

Anthocyanin $(\mu \mathrm{mol} / \mathrm{mL})=0.08173 A_{537}-0.00697 A_{647}-$ $0.002228 A_{663}$

Chlorophyll a $(\mu \mathrm{mol} / \mathrm{mL})=0.01373 A_{663}-0.000897 A_{537}-$ $0.003046 A_{647}$

Chlorophyll b $(\mu \mathrm{mol} / \mathrm{mL})=0.02405 A_{647}-0.004305 A_{537}-$ $0.005507 A_{663}$

Carotenoids $(\mu \mathrm{mol} / \mathrm{mL})=\left[A_{470}-(17.1 \times\right.$ (Chlorophyll $\mathrm{a}+$ Chlorophyll b) $-9.479 \times$ Anthocyanin) $] / 119.26$

\section{Determination of the Antioxidant Activity (Free Radical Scavenging Activity)}

The leaf parts were chopped and dried at room temperature for 10 days and used for the preparation of ethanolic extract. The free radical scavenging activities of ethanolic extracts and the standard L-ascorbic acid (vitamin C) were measured in terms of radical scavenging ability, using the stable radical 1, 1-diphenyl-2-picrylhydrazyl (DPPH). Three $\mathrm{mL}$ of 0.1 $\mathrm{mM}$ solution of DPPH in alcohol was added to $1 \mathrm{~mL}$ various concentrations $(100-2000 \mu \mathrm{g} / \mathrm{mL})$ of ethanolic extracts of leaves or standard L- ascorbic acid of $10-100 \mu \mathrm{g} / \mathrm{mL}$. Absorbance was taken after 30 minutes at $517 \mathrm{~nm}$ using a UV-spectrophotometer. The \% inhibition was calculated using the following formula [12],

$$
\left[\left(A_{0}-A_{1}\right) / A\right] \times 100
$$

where, $A_{0}$ - absorbance of the control (ethanol); $\mathrm{A}_{1}$ absorbance of extract or standard (ascorbic acid)

The antioxidant reacts with stable free radical, DPPH and converts it to1, 1-diphenyl-2-picryl hydrazine. The ability to scavenge the free radical, DPPH, was measured. Standard L-ascorbic acid was taken as reference which showed 34.92 $\mu \mathrm{g} / \mathrm{mL}$ of $\%$ inhibition (Fig. 1).

\section{E. Comparison of the Postharvest Keeping Quality of Four A. Tricolor Accessions under Different Storage Conditions}

The crop was harvested 40-45 days after sowing. Bundles of $250 \mathrm{~g}$ of leaves (including stems) were prepared and each bundle served as a replicate. Storage conditions used were:
$T 1($ control $)=$ cut stem ends dipped in tap water and stored under ambient conditions $\left(27 \pm 2{ }^{\circ} \mathrm{C}\right.$ and $\left.60 \% \mathrm{RH}\right)$, leaves sprayed with $200 \mathrm{~mL}$ tap water daily, $T 2$ = packaged in low density polyethylene bags (LDPE $150 \mu \mathrm{m}$ gauge film; $60 \times$ $30 \mathrm{~cm}^{2}$ sized bag) and stored under ambient conditions, $T 3=$ packaged in LDPE film bags and stored under $10{ }^{\circ} \mathrm{C}$ and $90 \%$ RH. Leaves were daily assessed for the \% weight loss. The visual quality was ranked using a self-prepared scale based on leaf wilting, yellowing and defoliation. Shelf life was determined as the time (in days) taken to show moderate wilting (for control samples) or moderate defoliation (for poly-film packed samples).

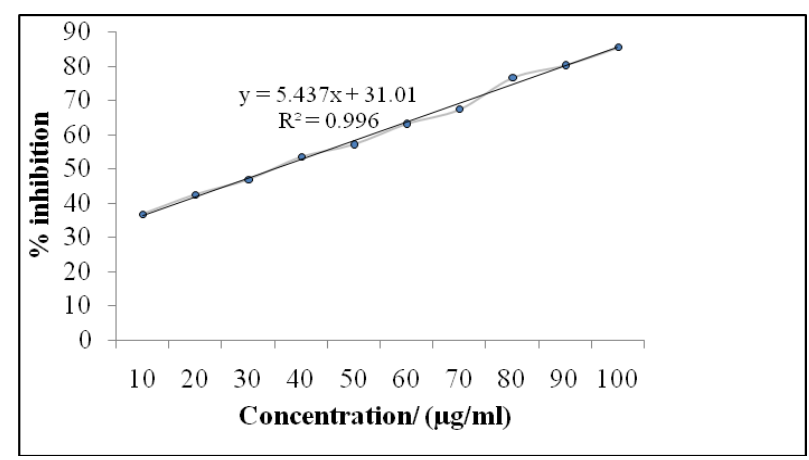

Fig. 1. Results of DPPH radical scavenging assay for standard ascorbic acid.

\section{F. Data Analysis}

Data were subjected to statistical analysis by SAS software package (1998). Growth, yield and biochemical parameters were analyzed by One-way ANOVA. Postharvest keeping quality was analyzed by Two-way ANOVA. Mean separation was done using LSD at $p \leq 0.05$ level.

\section{RESUlts}

\section{A. Comparison of Growth and Yield Parameters of Four Accessions of A. Tricolor}

Among the growth parameters tested, plant height, number of leaves, weight of fresh leaf and plant, fresh and dry weight of stem and roots and total yield differed significantly (Table I). 'Pure green' showed significantly higher yield throughout the tested period. There was no genotype $\mathrm{X}$ environment interaction observed with 'Pure green' (Table II).

\section{B. Crude Protein Levels}

'DOA green' leaves had the highest level of crude protein while 'Pure green' showed the lowest (Table III).

\section{Carotenoid, Chlorophyll and Anthocyanin Levels}

There was a significant variation observed in pigment contents among the accessions (Table III). 'DOA Red' contained higher amounts of chlorophylls and anthocyanin while higher levels of carotenoids were recorded in 'Pure green'.

\section{Antioxidant Activity}

'DOA Red' exhibited the highest DPPH free radical scavenging (antioxidant) activity as indicated by the lowest $\mathrm{IC}_{50}$ value. 'DOA green' showed the lowest antioxidant activity (Table IV). 
TABLE I: GROWTH PERFORMANCE OF FOUR ACCESSIONS OF AMARANTHUS TRICOLOR

\begin{tabular}{|c|c|c|c|c|}
\hline \multirow[b]{2}{*}{ Parameter } & \multicolumn{4}{|c|}{ Accession } \\
\hline & 'DOA Red' & 'DOA green' & 'Pure green' & 'Diyapalagoda' \\
\hline Plant height $(\mathrm{cm})$ & $65.90^{\mathrm{b}}$ & $65.44^{\mathrm{b}}$ & $70.39^{b}$ & $77.68^{\mathrm{a}}$ \\
\hline Stem circumference $(\mathrm{cm})^{*}$ & 3.79 & 3.78 & 3.80 & 23.47 \\
\hline Number of leaves & $38.90^{\mathrm{c}}$ & $43.85^{\mathrm{c}}$ & $85.58^{a}$ & $53.05^{\mathrm{b}}$ \\
\hline Length of $6^{\text {th }}$ leaf $(\mathrm{cm})^{*}$ & 20.18 & 19.39 & 19.61 & 19.80 \\
\hline Width of $6^{\text {th }}$ leaf $(\mathrm{cm})^{*}$ & 13.86 & 13.14 & 13.07 & 15.78 \\
\hline $3^{\text {rd }}$ internodal length $(\mathrm{cm})^{*}$ & 2.99 & 3.31 & 3.71 & 3.30 \\
\hline Fresh weight per plant (g) & $174.77^{\mathrm{b}}$ & $188.06^{\mathrm{b}}$ & $281.25^{\mathrm{a}}$ & $278.00^{\mathrm{a}}$ \\
\hline Fresh leaf weight (g) & $62.89^{\mathrm{b}}$ & $63.68^{\mathrm{b}}$ & $96.36^{\mathrm{a}}$ & $84.29^{\mathrm{a}}$ \\
\hline Dry leaf weight $(\mathrm{g})^{*}$ & 6.38 & 6.74 & 8.07 & 7.53 \\
\hline Fresh stem weight (g) & $71.18^{\mathrm{b}}$ & $77.47^{\mathrm{b}}$ & $120.15^{\mathrm{a}}$ & $126.09^{\mathrm{a}}$ \\
\hline Dry stem weight (g) & $3.70^{\mathrm{b}}$ & $4.02^{\mathrm{b}}$ & $6.26^{\mathrm{a}}$ & $6.60^{\mathrm{a}}$ \\
\hline Fresh root weight (g) & $16.47^{\mathrm{b}}$ & $13.66^{\mathrm{b}}$ & $33.81^{\mathrm{a}}$ & $35.76^{\mathrm{a}}$ \\
\hline Dry root weight (g) & $1.57^{\mathrm{cb}}$ & $1.37^{\mathrm{c}}$ & $2.37^{\mathrm{a}}$ & $2.89^{\mathrm{a}}$ \\
\hline
\end{tabular}

Mean values followed by different letters in the column are significantly different at $\mathrm{P} \leq 0.05$ level

* Not significantly different at $P \leq 0.05$

TABLE II: YIELDING ABILITY OF FOUR ACCESSIONS OF AMARANTHUS TRICOLOR IN FOUR DIFFERENT SEASONS

\begin{tabular}{|c|c|c|c|c|}
\hline \multicolumn{5}{|c|}{ Yield (mt/ ha) } \\
\hline Accession & Season 1 & Season 2 & Season 3 & Season 4 \\
\hline 'DOA Red' & $17.64^{\mathrm{c} 2}$ & $21.44^{\mathrm{cl}}$ & $19.13^{\mathrm{b} 2}$ & $16.42^{\mathrm{c} 2}$ \\
\hline 'DOA green' & $22.48^{b 1}$ & $24.76^{\mathrm{cl}}$ & $11.89^{\mathrm{b} 3}$ & $21.93^{b 1}$ \\
\hline 'Pure green' & $32.24^{\text {al }}$ & $36.72^{\mathrm{a} 1}$ & $27.93^{\mathrm{a} 1}$ & $34.33^{\mathrm{a} 1}$ \\
\hline 'Diyapalagoda' & $22.09^{\mathrm{b} 2}$ & $31.01^{\mathrm{ab} 1}$ & $22.30^{\mathrm{ab} 2}$ & $24.46^{\mathrm{b} 2}$ \\
\hline
\end{tabular}

Mean values followed by different letters in the rows and numbers in the columns are significantly different at $P \leq 0.05$ level

\section{E. Comparison of the Postharvest Keeping Quality under} Different Storage Conditions

The shelf life of $A$. tricolor varied significantly $(\mathrm{p} \leq 0.05)$ among storage conditions and accessions (Table V). 'DOA Red' showed the longest shelf life under all three storage conditions. Leaf samples stored without LDPE packaging had the shortest shelf life. The quality deterioration was mainly due to wilting resulted from rapid water loss (loss of fresh weight; Fig. 2). Polyethylene film-packaging was effective in extending the shelf life significantly $(p \leq 0.05)$ both under ambient temperature and $10^{\circ} \mathrm{C}$ mainly through reduction of water loss. In all four $A$. tricolor accessions, polyethylene film-packed samples stored under $10{ }^{\circ} \mathrm{C}$ (T3) showed the best postharvest longevity. Under T3, 4.8-fold, 5.5-fold, 6-fold and 8-fold extension of shelf life was observed in 'DOA Red', 'DOA green', 'Pure green' and 'Diyapalagoda', respectively, compared to control (T1). The polyfilm-packed samples did not show any signs of wilting during storage but some defoliation could be seen.

TABLE III: CRUde Protein, CARotenoids, Chlorophyll AND ANTHOCYANIN LEVELS IN THE FOUR ACCESSIONS OF AMARANTHUS TRICOLOR

\begin{tabular}{lccccc}
\hline Assession & \% crude & Anthocyanin & Chlorophyll a & Chlorophyll b & Carotenoids \\
\cline { 3 - 6 } & protein & $\boldsymbol{\mu g} / \mathbf{c m}^{2}$ & $\boldsymbol{\mu g} / \mathbf{c m}^{\mathbf{2}}$ & $\boldsymbol{\mu g} / \mathbf{c m}^{\mathbf{2}}$ & $\boldsymbol{\mu g} / \mathbf{c m}^{\mathbf{2}}$ \\
\hline 'DOA Red' & $23.63^{\mathrm{ab}}$ & $1.738^{\mathrm{a}}$ & $9.796^{\mathrm{e}}$ & $3.075^{\mathrm{i}}$ & $3.846^{\mathrm{xy}}$ \\
'DOA green' & $24.80^{\mathrm{a}}$ & $0.723^{\mathrm{a}}$ & $2.223^{\mathrm{f}}$ & $2.816^{\mathrm{ij}}$ & $4.815^{\mathrm{x}}$ \\
'Pure green' & $22.80^{\mathrm{b}}$ & $1.224^{\mathrm{a}}$ & $2.376^{\mathrm{f}}$ & $2.983^{\mathrm{ij}}$ & $5.155^{\mathrm{x}}$ \\
'Diyapalagoda' & $23.43^{\mathrm{b}}$ & $1.375^{\mathrm{a}}$ & $8.896^{\mathrm{ef}}$ & $2.461^{\mathrm{j}}$ & $3.628^{\mathrm{y}}$
\end{tabular}

\footnotetext{
Mean values followed by different letters in each row are significantly different at $P \leq 0.05$ level
}

\section{DISCUSSION}

Growth and yield performance, varietal adaptability, some nutritional aspects and postharvest keeping quality were investigated for four accessions of A. tricolor. Yield potential is determined by genetic makeup of the plant and 
environmental factors [13]. Among the tested accessions, 'Pure green' exhibited the best growth and yielding ability. The highest leaf: stem ratio was also recorded for the same accession (data not shown), which enhances the marketable value and consumer preference. Furthermore, absence of genotype $\mathrm{x}$ environment interaction over four consecutive seasons evidenced the wider adaptability of 'Pure green'. It is known that the adaptability of a crop cultivar is a consequence of cultivar's relatively high mean productivity (yield) and yield stability across environments either in locations or seasons or both [14]. 'Diyapalagoda' exhibited the highest plant height and root weight. Higher growth rate favors several harvests in a season and well developed root system provides the ability to grow under wide range of climatic condition in Amaranth. The growth performance observed in 'Diyapalagoda' indicated its suitability for home garden cultivation.

TABLE IV: DPPH RADICAL SCAVENGING ACTIVITY OF FOUR ACCESSIONS OF AMARANTHUS TRICOLOR ETHANOLIC EXTRACTS AND STANDARD ASCORBIC ACID

\begin{tabular}{llcc}
\hline Sample & Equation & $\mathbf{R}^{2}$ & $\mathbf{I C}_{\mathbf{5 0}}$ values $(\boldsymbol{\mu g} / \mathbf{m L})$ \\
\hline Standard Ascorbic acid & $\mathrm{y}=5.437 \mathrm{x}+31.01$ & 0.996 & 34.92 \\
'DOA Red' & $\mathrm{y}=0.026 \mathrm{x}+37.18$ & 0.997 & 493.07 \\
'DOA green' & $\mathrm{y}=0.021 \mathrm{x}+25.60$ & 0.994 & 1161.91 \\
'Pure green' & $\mathrm{y}=0.014 \mathrm{x}+35.72$ & 0.992 & 1020.00 \\
'Diyapalagoda' & $\mathrm{y}=0.020 \mathrm{x}+35.57$ & 0.991 & 721.50 \\
\hline
\end{tabular}

$\mathrm{IC}_{50}$ value denotes the concentration required to achieve $50 \%$ inhibition of antioxidant activity

TABLE V: SHELF LIFE OF Four ACCESSIONS OF AMARANTHUS TRICOLOR UNDER DiFFERENT STORAGE CONDITIONS

\begin{tabular}{|c|c|c|c|}
\hline \multirow[b]{2}{*}{ Accession } & \multicolumn{3}{|c|}{ Shelf life (days after harvest) } \\
\hline & $\begin{array}{c}\text { Water-sprayed (control) } \\
\left(27^{\circ} \mathrm{C}, 60 \% \mathbf{R H}\right)\end{array}$ & $\begin{array}{l}\text { Polyethylene film-packed } \\
\qquad\left(27^{\circ} \mathrm{C}, 60 \% \mathrm{RH}\right)\end{array}$ & $\begin{array}{l}\text { Polyethylene film-packed } \\
\qquad\left(10^{\circ} \mathrm{C}, 90 \% \mathbf{R H}\right)\end{array}$ \\
\hline 'DOA Red' & 2.5 Аа & $6^{\mathrm{Ab}}$ & $12 \mathrm{Ac}$ \\
\hline 'DOA green' & 2 ва & $5^{\mathrm{Bb}}$ & $11^{\mathrm{Bc}}$ \\
\hline 'Pure green' & $1.5 \mathrm{Ca}$ & $4 \mathrm{Cb}$ & $9^{\mathrm{Cc}}$ \\
\hline 'Diyapalagoda' & $1 \quad \mathrm{Da}$ & $3 \mathrm{Db}$ & $8^{\mathrm{Dc}}$ \\
\hline
\end{tabular}

Mean values in each row followed by different letters are significantly different at $p \leq 0.05$ level. Uppercase letters denote accession effect whereas lowercase letters denote treatment effect.

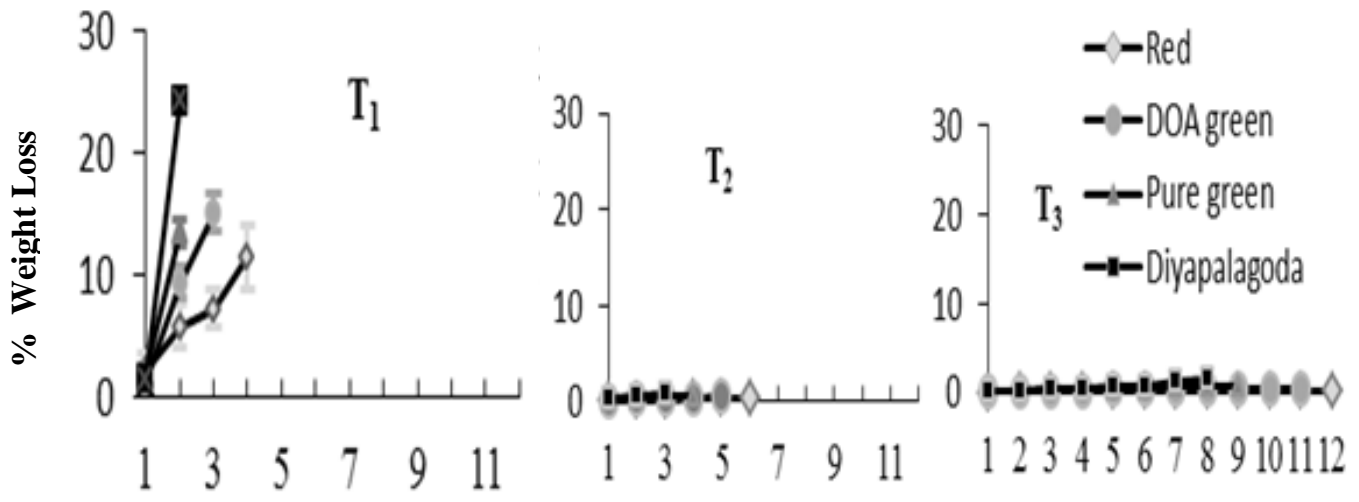

Days after harvest

Fig. 2. Effect of storage conditions on water loss by leaves of four accessions of Amaranthus tricolor $\left(T 1=\right.$ control (without package and stored at $27^{0} \mathrm{C}, T 2=$ Packaged and stored at $27^{\circ} \mathrm{C}, 73=$ Packaged and stored at $10^{\circ} \mathrm{C}$ )

In the present study, \% crude protein varied among genotypes. Crop varieties differ slightly in their ability to convert soil nitrogen to protein. Higher protein varieties tend to have lower yields and vice versa [15]. Amaranth has been reported as one of the many vegetables to be rich in antioxidant components [16]. Carotenoids, ascorbic acid, flavonoids, chlorophylls and its derivatives [17] and phenolic compounds are some of the components which contribute to antioxidant activity through their ability to neutralize free radicals by donor electron, without becoming active free radicals [18]. Anthocyanins in red colour vegetables are reported to contribute significantly to antioxidant activity [19]. Among the accessions tested, 'DOA Red' showed the highest antioxidant activity and this might be due to its apparently higher total pigment content compared to that in other accessions. Factors such as maturity and genetic 
variability can also influence the antioxidant capacity of vegetables [20]. The results of the present study agree with the fact that the total content of above pigments has a direct relationship with the antioxidant activity.

The postharvest longevity is partly under genetic control and can be manipulated by breeding and postharvest practices [21]. Packaging of leaves with LDPE film is beneficial in improving the shelf life through maintaining a high relative humidity in surrounding atmosphere reducing the water loss from the fresh produce [22]. Premature deterioration in product quality due to respiration is also reduced due to the establishment of modified atmospheric condition (MAP) inside the poly-film package [23]. Low temperature storage extends shelf life by further reducing water loss, restricting enzymatic activity thereby reducing respiratory and ethylene production rates [24].

Crude protein levels detected for all four accessions were within $22-25 \%$ on dry weight basis. Although 'DOA Red' showed the highest antioxidant activity, the consumer preference for this accession was low mainly due to its red colour (data not shown). Considering growth and yield performance and adaptability, 'Pure green' could be considered for commercial cultivation.

\section{REFERENCES}

[1] J. R. Ehleringer, "Ecophysiology of Amaranthus palmeri, a Sonoran Desert summer," Annual Oecologia, vol. 57, pp. 107-112, 1983.

[2] J. S. Oliveira and M. F. De Carvalho, "Nutritional value of some edible leaves used in Mozambique," Journal of Economic Botany, vol. 29, no. 4, pp. 255-263, 1975 .

[3] O. L. Oke, Amaranth, Handbook of Tropical Foods, 2 nd ed. New York, 1983, pp. 1-14.

[4] K. J. Hunter and J. M. Fletcher, "The antioxidant activity and composition of fresh, frozen, jarred and canned vegetables," Innovative Food Science and Emerging Technology, vol. 3, pp. 399-406, 2002.

[5] A. Romani, P. Pinelli, C. Galardi, G. Sani, A. Cimato, and D. Heimler, "Polyphenols in greenhouse and open-air-grown lettuce," Food Chemistry, vol. 79, pp. 337-342, 2002.

[6] M. C. Palada and L. C. Chang, "Suggested cultural practices for vegetable amaranth," International Cooperators Guide AVRDC, vol. 3, no. 6 , pp. 552-556, 2003.

[7] K. B. Wahundeniya, "Present status of leafy vegetables," Journal of Agricultural and Food Chemistry, vol. 1, pp. 1-6, 2008.

[8] M. Ogunlesi, W. Okiei, E. A. S. Osibote, and C. Muotoh, "Antimicrobial activity of the essential oil and the fractional samples obtained from the leaves and seeds of Phyllanthus amarus (Euphorbiaceae)," The Research Journal of Phytochemistry, vol. 3, no. 4, pp. 77-84, 2009.

[9] P. Cunniff, "Official methods of analysis," 16th ed. Association of Official Analytical Chemists International (AOAC), 1998, pp. 984.

[10] H. K. Lichtenthaler and A. R. Wellburn, "Determinations of total carotenoids and chlorophylls a and b of leaf extracts in different solvents," Biochemical Society Transactions, vol. 11, pp. 591-592, 1983.

[11] A. S. Daniel and A. G. John, "Relationships between leaf pigment content and spectral reflectance across a wide range of species, leaf structures and developmental stages," Remote Sensing of Environment, vol. 81 , pp. 337-354, 2002.

[12] A. Patel, A. Patel, and N. M. Patel, "Determination of polyphenols and free radical scavenging activity of Tephrosia purpurealinn leaves (Leguminosae)," Journal of Pharmacognocy Research, vol. 2, no. 3, pp $152-158,2010$

[13] M. A. U. Malik, A. Haji, I. BukhshHussain, M. A. Athar, and M. Ali, "Comparative performance of some new wheat cultivars in agro-ecological zone of Dera Ghazi Khan,” The Journal of Animal \& Plant Sciences vol. 19, no. 2, pp. 78-81, 2009.

[14] M. Anputhas, S. Samita, and D. S. Abeysiriwardena, "Stability and adaptability analysis of rice cultivars using environment center edyield in two-way ANOVA model," Communications in Biometry and Crop Science vol. 6, no. 2, pp. 80-86, 2011.

[15] R. H. McKenzie, A. B. Middleton, R. Dunn, R. S. Sadasivaiah, and E. Bremer, "Response of irrigated soft white spring wheat to seeding date, seeding rate and fertilization," Canadian Journal of Plant Science vol. 88, pp. 291-298, 2008

[16] I. Amin, M. M. Zamaliah, and W. F. Chin, "Total antioxidant activity and phenolic content in selected vegetables," Food Chemistry vol. 87 pp. 581-586, 2004.

[17] M. G. Ferruzzi, V. Böhm, P. D. Courtney, and S. J. Schwartz, "Antioxidant and antimutagenic activity of dietary chlorophyll derivatives determined by radical scavenging and bacterial reverse mutagenesis assays," Journal of Food Science vol. 67, no. 7, pp. 2589-2595, 2002

[18] A. Mortensen, L. H. Skibsted J., Sampson, E. C. Rice, and S. A. Everett, "Comparative mechanisms and rates of free radicals cavenging by carotenoid antioxidants," FEBS Journal vol. 418 pp. 91-97, 1997.

[19] Y. S. Velioglu, G. Mazza, L. Gao, and B. D. Oomah, "Antioxidant activity and total phenolics in selected fruits, vegetables and grain products," Journal of Agricultural and Food Chemistry, vol. 46, pp. 4113-411, 1998.

[20] R. L. Prior, G. Cao, A. Martin, E. Sofic, J. O. McEwen, and C. Brien, "Antioxidant capacity as influenced by total phenolic and anthocyanin content, maturity, and variety of Vacciniumspecies," Journal of Agricultural and Food Chemistry, vol. 46, pp. 2686-2693, 1998

[21] S. Kanlayanarat, "Postharvest technologies for fresh leafy vegetables in Thailand," in Proc. RETA 6376 Workshop on Best Practices in Postharvest Management of Leafy Vegetables in GMS Countries, Hanoi, Vietnam, 2007, pp. 25-27.

[22] A. A. Kader, Postharvest Technology of Horticultural Crops. 3 rd ed. Oakland University of California: Division of Agriculture and Natural Resources Publication, 2006, pp. 535

[23] O. K. Bautista and A. L. Acedo, Postharvest handling of fruits and vegetables. Manila: National Book. Techguide Series no. 4, pp. 24, 1987.

[24] L. Kitinoja and A. A. Kader, Small-scale Postharvest Handling Practices: A Manual for Horticultural Crops, 4th ed., Postharvest Horticulture Series vol. 8E, pp. 260, 2002.

Ms. P. Malathy is working as a Plant breeder in the Department of Agriculture, Sri Lanka. Her current research interest is mainly on breeding of quality and high nutritional value vegetables and potato. She is a recipient of the 'Young Scientist Award for the outstanding contribution for the Agricultural development in Sri Lanka' in 2002.

Ms. D. D. Suraweera is working as an Instructor in the Department of Botany, University of Peradeniya, Sri Lanka and now following a MSc. degree in Biotechnology, in the same University. Her current research interest is mainly on Plant Biochemistry and Plant Physiology.

Dr. W. A. M. Daundasekera is a Senior Lecturer in the Department of Botany, University of Peradeniya, Sri Lanka. Her current research interest is mainly on Postharvest Technology of tropical fruits and vegetables. She is a recipient of the 'Presidential Awards for Scientific Research in Sri Lanka' in 2003

Ms. W. D. G. P. Nilanthi is a Program Assistant in the Department of Agriculture, Sri Lanka. Her current research interest is on Plant breeding.

Mr. K. B. Wahundeniya is currently serving as the Actg Director of the Horticultural Crops Research and Development Institute, Sri Lanka. His current research interests are developing strategies for climate changes, and controlled environmental studies for horticultural crop improvement. 